\title{
Thyroxine Metabolism in Cultured Cells Derived from Fetal Rat Lung
}

\author{
MARGOT SEGALL-BLANK, WILLIAM H. J. DOUGLAS, RONALD L. SANDERS, AND \\ KAREN R. HITCHCOCK ${ }^{(43)}$ \\ Department of Anatomy and Cellular Biology, Tufts University School of Medicine, Boston, Massachusetts, USA
}

\begin{abstract}
Summary
The role of thyroxine $\left(T_{4}\right)$ in fetal lung development has been demonstrated previously. Because triiodothyronine $\left(T_{3}\right)$, not $T_{4}$, is thought to be the active hormone, and because $T_{3}$ nuclear receptors appear to be present in fetal lung, the following studies were performed to examine peripheral metabolism of $\left[{ }^{125} I\right] T_{4}$ by organotypic and mixed monolayer cultures of fetal lung cells. The cells were derived from fetal rat lungs obtained at 16 and 19 days of gestation.

Short term $(2 \mathrm{~h})$ incubations of homogenized organotypic cultures and mixed monolayer cultures with $\left[{ }^{125} \mathrm{ITT}_{4}\right.$ showed minimal amounts of ${ }^{125} \mid T_{3}$ generation expressed as $\%$ added $T_{4}$ per mg protein $(0.43 \pm 0.32$ and $0.56 \pm 0.28$, respectively). In addition, there appeared to be "excess iodide" (2.21) and substantial generation of $\mathrm{rT}_{3}$ (i.e., $2.67 \pm 1.1$ and $1.87 \pm 1.0$, respectively).

In a subsequent group of experiments, deiodination of $\left[{ }^{125} I\right] T_{4}$ was allowed to proceed by incubating intact organotypic cultures with $\left[{ }^{125} \mathrm{I}\right] \mathrm{T}_{4}$ for longer periods $(36 \mathrm{~h})$. Subsequent assessment and comparison of deiodination products in the subcellular fractions showed that the highest $\%$ of $\left[{ }^{125} \mathrm{I}\right] \mathrm{T}_{3}$ (relative to total thyronines) was present in the fraction enriched with nuclei $(7.7 \pm 2.3)$. This was significantly different from the $\left[{ }^{125} I\right] T_{3}$ in homogenized whole cells $(4.54 \pm 1.5)$, and markedly different from the medium which contained the lowest $\%$ of $\left[{ }^{125} \mathrm{I}\right] \mathrm{T}_{3}(0.18 \pm 0.2)$. Further confirmation was obtained to show that this high concentration of $\left.{ }^{125}{ }^{12}\right] T_{3}$ in the nuclear fraction had in fact been generated de novo and did not merely result from redistribution of labeled hormones among the cellular compartments. Incubation of organotypic cultures with two different isotopically-labeled hormones $\left(\left[{ }^{131} I\right] T_{3}\right.$ and $\left.\left[{ }^{125} I\right] T_{4}\right)$ permitted calculation of nuclear to medium ratios for $\left[{ }^{131} I\right] T_{3}$ and $\left.{ }^{[125} \mathrm{I}\right] \mathrm{T}_{3}$; the ratio of these provided an index of intracellular conversion of $\left[{ }^{125} I\right] T_{4}$ to $\left[{ }^{125} I\right] T_{3}$. The mean of five such experiments demonstrated that of the total $\left[{ }^{125} I\right] T_{3}$ attached to the nuclear fraction at the end of the incubation, $32 \%$ was newly generated and $68 \%$ was derived by influx from the medium. These results indicate that organotypic cultures derived from day 19 fetal rat lung are capable of deiodinating $T_{4}$ and that both $r T_{3}$ and $T_{3}$ are generated. The generated $T_{3}$ appears to be retained by the lung cells and is bound to the nuclear fraction. On the other hand, $\mathbf{r T}_{3}$ is distributed more evenly throughout the cell and in the medium and presumably is not bound.
\end{abstract}

\section{Abbreviations}

DIMIT, 3,5-dimethyl-3'-isopropyl-L-thyronine

FBS, fetal bovine serum

PC, phosphatidylcholine

$\mathbf{T}_{3}$, triiodothyronine

$\mathbf{r} \mathbf{T}_{3}$, reverse $\mathbf{T}_{3}$

$T_{4}$, thyroxine

TAA, hexane-tertiary amyl alcohol-2 $\mathrm{N}$ ammonia

The role of thyroid hormone in fetal lung development is well recognized, but its mechanism of action is not clear $(20-22,27$,
38). The hormonal milieu of the mammalian fetus is characterized by low triiodothyronine $\left(T_{3}\right)$ levels and high concentrations of reverse $\mathrm{T}_{3}\left(\mathrm{rT}_{3}\right)(16,38)$; and yet, certain target organs, including the lung, appear to depend on the active form of thyroid hormone (i.e., $\mathrm{T}_{3}$ ) during certain developmental stages.

Early studies by Redding et al. (27) showed that thyroidectomy and subsequent thyroid hormone replacement profoundly influenced the morphologic characteristics of type II pneumonocytes and their lamellar bodies, and that there was a correlation between the demonstrated ultrastructural changes and lung surfactant secretion. More recently, Hitchcock and collaborators (20-22) demonstrated that thyroxine $\left(\mathrm{T}_{4}\right)$ can accelerate rat lung development and that this acceleration is maximal in the presence of glucocorticoids. Similar findings were noted by Ballard and associates (1, 2) during transplacental stimulation of fetal rabbit lung by an analog of $\mathrm{T}_{4}$ known as DIMIT. The effects of hormones on fetal lung metabolism have also been studied using fetal lung cells under conditions of short term monolayer culture. Smith and Torday (33), using monolayer cultures of fetal rabbit lung cells, found that $T_{4}$ produced a significant increase in incorporation of $\left[{ }^{14} \mathrm{C}\right]$-choline into PC. In a similar tissue culture system, Farrell $e t$ al. (14) have shown an increase in activity of cholinekinase, and both $\mathrm{T}_{4}$ and cortisol exposure led to an increase in choline phosphotransferase.

With the increasing evidence that most, if not all, actions of thyroid hormone are expressed by $\mathrm{T}_{3}$, there have been additional investigations of the effect of $T_{3}$ on lung development. Using organotypic cultures of fetal rat lung alveolar type II cells, we found that $T_{3}$ had a stimulatory effect on the synthesis of PC (34). The importance of $\mathrm{T}_{3}$ has also been indicated by the demonstration of specific high affinity $T_{3}$ binding sites in the lung $(3,17)$.

The apparent role of $T_{3}$ in developing lung as well as other organs has been particularly interesting in the face of the normally low serum concentrations of $T_{3}$ present during the perinatal period $(16,38)$. Additionally, in the rat, serum $\mathrm{T}_{3}$ concentrations remain low through the first week of postnatal life. One explanation could be that $T_{3}$ is generated at the particular local sites of action. In this study, peripheral pathways of thyronine metabolism were investigated in a well-characterized organotypic culture system enriched in type II alveolar epithelial cells. Similar pathways have already been demonstrated in a variety of other fetal organs (29) and in carcino-fetal cell lines $(28,36)$.

\section{MATERIALS AND METHODS}

Preparation of organotypic cultures of type II alveolar epithelial cells $(11,12)$. Dated-pregnant Sprague-Dawley rats (39) were sacrificed on day 19 of gestation by $\mathrm{CO}_{2}$ asphyxiation. The litters were immediately delivered by hysterotomy using aseptic techniques, and the fetal lungs removed.

The lungs were minced, washed in RPMI-1640 tissue culture medium and enzymatically dissociated in $0.1 \%$ trypsin, $0.1 \%$ collagenase and $1 \%$ chicken serum in saline at $37^{\circ} \mathrm{C}$ for $20 \mathrm{~min}$, as described previously (12). The supernatant was carefully aspirated and filtered through a $100-\mu \mathrm{m}$ and a $41-\mu \mathrm{m}$ filter. This procedure 
was repeated several times until the majority of the lung was digested. The filtered suspension of freshly isolated cells was centrifuged at $260 \times g$ for $5 \mathrm{~min}$ and the pellet resuspended in a small volume of RPMI-1640 medium containing 10\% FBS. Cells were counted in an haemocytometer and the cell suspension adjusted to contain a final concentration of $10^{8}$ viable cells $/ \mathrm{ml}$ Aliquots of $100 \mu \mathrm{l}$ of this cell suspension were seeded onto a gelfoam square and incubated in $100-\mathrm{mm}$ petri dishes in a volume of $25 \mathrm{ml}$ RPMI-1640 tissue culture medium supplemented with $10 \%$ FBS. The cells were maintained on gelfoam sponges for 2-3 days and allowed to aggregate to form organotypic cultures (12).

$\left.{ }^{125} I\right] T_{4}$ incubation experiments. Subsequent to the initial incubation, the gelfoam was digested with collagenase and the cells grown for $18-24 \mathrm{~h}$ in short term monolayer culture in RPMI-1640 medium supplemented with $1 \%$ FBS. At the time of harvest, the monolayer cultures were washed with Moscona's saline solution and then incubated with $\left[{ }^{125} \mathrm{IJT}_{4}\right.$ (39) according to one of the following procedures.

In one set of experiments, the cells were first homogenized and then incubated with labeled hormone. In another series of experiments, labeled $T_{4}$ was added to the cells while they were still attached to the culture plates (i.e., before the cell homogenization step).

Deiodination of $\left[{ }^{125} I J T_{4}\right.$ by organotypic and mixed monolayer cultures of type II cells homogenized before incubation. The methodology utilized for this study is similar to that previously described for deiodination experiments in liver $(4,5)$, kidney, and pituitary (7). Briefly, fresh tissue is obtained, immediately homogenized, and then incubated with labeled hormone in buffer for short periods of time (i.e., $2-3 \mathrm{~h}$ ), usually in the presence of a sulfhydryl reducing agent (i.e., $20 \mathrm{mM}$ dithiothreitol, see ref. 39) In the present experiments, isolated cells were substituted for fresh tissue. Two types of cells were employed: (1) organotypic cell cultures prepared on gelfoam squares according to the method already described and (2) mixed monolayer cultures consisting predominantly of type II epithelial cells $(33,41)$.

After harvesting the cells, a pellet containing $5 \times 10^{7}$ cells was homogenized gently with a glass pestle and the cells suspended in $300 \mu$ l of $0.15 \mathrm{M}$ phosphate buffer enriched with dithiothreitol (20 $\mathrm{mM}$ ). One ng of $\left[{ }^{125} \mathrm{I}\right] \mathrm{T}_{4}$ (specific activity, $1023 \mu \mathrm{Ci} / \mu \mathrm{g}$ ) was added and the mixture was incubated for $3 \mathrm{~h}$ at $37^{\circ} \mathrm{C}$ in a shaking water bath. The reaction was terminated by the combination of equal parts of homogenate and methanol: $2 \mathrm{~N}$ ammonia (99:1). Ten $\mu$ aliquots were chromatographed in a descending hexane-tertiary amyl alcohol-2 $\mathrm{N}$ ammonia (1:10:11) solvent system (TAA).

In this and all other experiments (see below), two different controls were utilized. In one (zero-time control), the methanol:ammonia was added immediately to the $\left[{ }^{125} I\right] T_{4}$ in order to measure any contaminants present in the tracer employed. In the other (post-incubation control), spontaneous deiodination of the tracer was assessed by adding the $\left[{ }^{125} \mathrm{I}\right] \mathrm{T}_{4}$ to buffer (or medium, see below), which was devoid of cells. All controls were incubated and analyzed in parallel with the cell samples. These controls provided correction factors that were used as a base from which the $\%$ of $\left[{ }^{125} \mathrm{I}\right] \mathrm{T}_{4}$ degradation and the $\%$ generation of labeled products could be calculated.

Deiodination of $\int^{125} I J T_{4}$ by intact cells in organotypic culture. Each plate containing $5 \times 10^{7}$ cells was carefully rinsed with Moscona's saline solution and the cells were then incubated for 36 $\mathrm{h}$ in medium enriched with $\left[{ }^{125} \mathrm{I}^{1} \mathrm{~T}_{4}\right.$ (specific activity, $1023 \mu \mathrm{Ci} / \mu \mathrm{g}$ ) to a final concentration of $4.0 \mathrm{ng}$ of $\mathrm{T}_{4} / \mathrm{ml}$ of medium. The petri dishes were maintained in an humidified atmosphere of $5 \% \mathrm{CO}_{2}$ in air at $37^{\circ} \mathrm{C}$. After $36 \mathrm{~h}$ incubation, the medium and cells were harvested separately. The cells were washed two times in Moscona's saline and a small aliquot was homogenized gently with a ground glass pestle providing a cell homogenate; the other portion was processed to yield a fraction enriched with nuclei according to a procedure adapted from Oppenheimer et al. by Silva and Larsen $(26,30-32)$. Briefly, the cells were homogenized in a solution containing $0.32 \mathrm{M}$ sucrose with $1 \mathrm{mM} \mathrm{MgCl}, 1 \mathrm{mM}$ $\mathrm{KH}_{2} \mathrm{PO}_{4}$ and 0.25 Triton, and centrifuged for $10 \mathrm{~min}$ at $700 \times \mathrm{g}$. The crude nuclear pellet was washed, resuspended in $0.32 \mathrm{M}$ sucrose with $3 \mathrm{mM} \mathrm{MgCl}$, and purified by passage through a concentrated sucrose gradient (30-32). The final pellet, enriched with nuclei, was counted in a gamma counter, and thyronine products of deiodination as well as any residual $\mathrm{T}_{4}$ were extracted in ethanol, and the extract chromatographed on paper in a descending TAA solvent system.

As in the previous studies, zero-time controls and cell-free medium post-incubation controls were run and analyzed in parallel with each experimental group.

Chromatography of reaction products. Ten $\mu \mathrm{l}$ of reaction mixture were applied as a spot, together with carrier compounds, to strips of Whatman No. 3 chromatography paper and were chromatographed in descent using the TAA solvent system. Iodide was identified by staining dried strips with palladium chloride $(0.1 \%)$. The locations of the radiolabeled thyronines were identified by carrier compounds, namely potassium iodide, $\mathrm{T}_{4}, \mathrm{rT}_{3}$, methimazole, and $\mathrm{T}_{3}$, which were visible with ultraviolet light. For further confirmation, radioautography was performed. The zones of radiolabeled thyronines were excised, as were the origins of the chromatograms, and their $\left[{ }^{125} \mathrm{I}\right]$ content separately determined in a scintillation counter. More than $98 \%$ of the total radioactivity recovered from the chromatograms between the origin and the solvent front was contained in five discrete zones identified as origin material, iodide, $\mathrm{rT}_{3}, \mathrm{~T}_{4}$, and $\mathrm{T}_{3}$. This technique provided the means for analyzing the contents of the subcellular fraction enriched with nuclei, whole cell homogenates and the medium. At the end of the incubation, iodide production and $T_{4}$ degradation were also compared in these same fractions. All results obtained were expressed as \% of $\left[{ }^{125} \mathrm{I}\right]$-labeled products generated, or degraded, relative to the total $\left[{ }^{125} \mathrm{I}\right] \mathrm{T}_{4}$ added $(4,5,29)$.

The $\left[{ }^{125} \mathrm{I}\right] \mathrm{T}_{4}$ utilized for the incubations was $95 \%$ pure, the major contaminants being $\left[{ }^{125} \mathrm{I}\right]$ iodide and from $0.4-0.7 \% \mathrm{~T}_{3}$. In addition, initial experiments indicated that spontaneous degradation of the $\left[{ }^{125} \mathrm{I}\right] \mathrm{T}_{4}$ occurred in the cell-free medium during the incubation period. Corrections were, therefore, made for $\left[{ }^{125} I\right] T_{3}$ and $\left[{ }^{125} I\right]$ contamination present in the $\left.{ }^{125}{ }^{12}\right] \mathrm{T}_{4}$ utilized, as well as for any labeled products found in the control cell-free medium preparations after the incubation.

In initial experiments, a zone of activity was detected in the region where $\mathrm{rT}_{3}$ normally migrates. In order to investigate this further, the chromatogram was re-chromatographed in two dimensions in a butanol-ethanol-ammonia system in order to separate $r T_{3}$ from $T_{1}$. In some instances, the $r T_{3}$ and $T_{1}$ spots were cut. out, eluted with ethanol and the eluted substances were again chromatographed in an ascending butanol-ethanol-ammonia system so that $\mathrm{rT}_{3}$ was clearly separated from $\mathrm{T}_{1}$

Incubation experiments utilizing two isotopes. The purpose of these experiments was to distinguish the proportion of $\left.{ }^{125} I\right] \mathrm{T}_{3}$ derived from simple influx from the medium surrounding the cells from that which was actually generated by $\left[{ }^{125} \mathrm{I}\right] \mathrm{T}_{4}$ deiodination $(8,30-32)$

After monolayer cultures $\left(5 \times 10^{7}\right.$ cells $)$ were established in 10 $\mathrm{ml}$ of RPMI, $\left[{ }^{125} \mathrm{I}\right] \mathrm{T}_{4}$ (specific activity, $1100-1200 \mu \mathrm{Ci} / \mu \mathrm{g}$ ) was added to a final concentration of $4.0 \mathrm{ng} / \mathrm{ml}$ of medium as already described. In addition, $\left[{ }^{131} \mathrm{I}\right] \mathrm{T}_{3}$ (specific activity, approximately $3000 \mu \mathrm{Ci} / \mu \mathrm{g}$ ) was added to the culture medium to a final concentration of $1.5 \mathrm{ng} / \mathrm{ml}$. The $\left.{ }^{131}{ }^{13}\right] \mathrm{T}_{3}$ utilized was prepared by iodination of $T_{3}$ using the cloramine $T$ method, and was purified by paper chromatography. The time course and experimental conditions for these incubation experiments were identical to those previously described for intact cells in organotypic culture. In addition, cell-free control studies were run as previously described to correct for tracer contamination, spontaneous degradation, and isotope decay.

The use of $\left[{ }^{131} \mathrm{I}\right] \mathrm{T}_{3}$ in addition to $\left[{ }^{125} \mathrm{I}\right] \mathrm{T}_{4}$ in this incubation system facilitated the assessment of $\mathrm{T}_{3}$ generated de novo versus that resulting from contamination of the radiolabeled $\mathrm{T}_{4}$ utilized, with subsequent transport into the cell $(8,30-32)$.

Because the $\left[{ }^{125} \mathrm{I}\right] \mathrm{T}_{4}$ utilized in this particular experiment contained from $0.3-0.6 \%\left[{ }^{125} \mathrm{I}\right] \mathrm{T}_{3}$, and because there was some generation of ${ }^{125} \mathrm{I}^{1} \mathrm{~T}_{3}$ in control, cell-free systems, a nuclear/medium ratio for $\left[{ }^{125} \mathrm{I}\right] \mathrm{T}_{3}$ was calculated for comparison with a similar 
nuclear/medium ratio for $\left[{ }^{131} \mathrm{I}\right] \mathrm{T}_{3}$. Employing such ratios, the $\%$ de novo $\mathrm{T}_{3}$ generation can be determined (8).

Explanation of terms. The portion of $\mathrm{T}_{3}$ concentrated in the subcellular fraction enriched with nuclei is termed " $N$," whereas that found in the medium surrounding the cells is designated "M."

Nuclear $T_{3}$ can be derived from three sources: $T_{3}\left(T_{3}\right)$ designates $\left[{ }^{131} \mathrm{I}\right] \mathrm{T}_{3}$ which has been transported from the pool of $\left.{ }^{[131} \mathrm{I}\right] \mathrm{T}_{3}$ in the medium; $\mathrm{T}_{3}\left(\mathrm{~T}_{4}\right)$ designates $\left[{ }^{125} \mathrm{I}\right] \mathrm{T}_{3}$ which is derived either from $\left[{ }^{125} \mathrm{I}\right] \mathrm{T}_{3}$ contaminating the $\left[{ }^{125} \mathrm{I}\right] \mathrm{T}_{4}$ added to the medium, or from actual monodeiodination of the added $\left[{ }^{125} \mathrm{I}\right] \mathrm{T}_{4}$. For purposes of clarity, these three sources of nuclear $T_{3}$ can be designated as $\mathrm{N}_{1}$, $N_{2}$ and $N_{3}$ where $N_{1}$ represents the $\left[{ }^{131} 1\right] T_{3}$ transported from the pool added to the medium [designated as $T_{3}\left(T_{3}\right)$ above], $N_{2}$ represents the $\left[{ }^{125} I\right] \mathrm{T}_{3}$ derived from the $\left[{ }^{125} \mathrm{I}\right] \mathrm{T}_{3}$ contaminating the $\left.{ }^{[25} \mathrm{I}\right] \mathrm{T}_{4}$ added to the medium, and $\mathrm{N}_{3}$ represents the $\left[{ }^{125} \mathrm{I}\right] \mathrm{T}_{3}$ derived from actual monodeiodination (i.e., newly generated $T_{3}$ ). $M_{1}$ and $M_{2}$ are employed to designate analogous sources of $T_{3}$ in the medium. Figure 1 illustrates these various possible sources of nuclear $T_{3}$ and depicts the compartmental analysis utilized for these experiments.

A nuclear to medium ratio (N:M) for either $\mathrm{T}_{3}$ isotope can be obtained by dividing the number of counts in the nuclear fraction per $\mathrm{mg}$ total homogenate protein by the number of counts in $1 \mathrm{ml}$ of medium. The N:M for $T_{3}\left(T_{3}\right)$ should be less than the $N: M$ for $\mathrm{T}_{3}\left(\mathrm{~T}_{4}\right)$ if actual $\mathrm{T}_{4} 5^{\prime}$-monodeiodination is taking place in the lung cells. In order, therefore, to determine the fraction of nuclear $\mathbf{T}_{3}$ derived simply from transport into the cell from the medium with subsequent nuclear binding, a ratio (" $\mathrm{X}$ ") can be calculated as follows:

$$
\text { "X" }=\mathrm{N}_{1} / \mathrm{M}_{1} \div \mathrm{N}_{2}+\mathrm{N}_{3} / \mathrm{M}_{2}\left[\text { or, } \mathrm{T}_{3}\left(\mathrm{~T}_{3}\right) \div \mathrm{T}_{3}\left(\mathrm{~T}_{4}\right)\right]
$$

The value thus determined subtracted from 1 , will determine the $\%$ of total bound nuclear $\mathrm{T}_{3}$ which is generated de novo.

Incubation experiments utilizing $\left.I^{125} I\right] T_{4}$ prepared by ion exchange column chromatography with subsequent net accounting of all labeled substances added during the experiment. In two experiments, $\left[{ }^{125} \mathrm{I}\right] \mathrm{T}_{4}$ was purified by passage through an ion exchange column as described by Sorimachi and Ui (35). This procedure provided $\left[{ }^{125} \mathrm{I}\right] \mathrm{T}_{4}$ which was virtually free of contamination by $\left[{ }^{125} \mathrm{I}\right] \mathrm{T}_{3}$ at the beginning of the incubation $(<0.2 \%)$. But even minimal amounts of $\left[{ }^{125} \mathrm{x}\right] \mathrm{T}_{3}$ can be concentrated by the cells; therefore, additional corrections for any shifts in labeled hormone concentrations in and out of cells were made by calculating all radioactive counts in the various compartments in order to assess a "net gain" of $\left[{ }^{125} \mathrm{I}\right]$ $\mathrm{T}_{3}$ content throughout the whole system (see "Appendix" for details).

Analysis of results of deiodination experiments after incubation with radiolabeled hormones. All incubation mixtures, monolayer cultures, whole cell homogenates, media, nuclei, and cells were examined for $\%$ degradation of $\mathrm{T}_{4}$ added, and for products of thyronine metabolism. All products were assessed by paper chromatography and radioautography. The results are expressed as $\%$ of total $\mathrm{T}_{4}$ counts added $/ \mathrm{mg}$ total homogenate protein.

Protein measurements. Protein determinations were carried out according to the method of Lowry et al. (25).

Statistical evaluation. Duncan's multiple range test (13) was used to assess the significance of differences between subcellular fractions, media, cells, and whole cell homogenates. In some instances the paired $t$ test was employed.

\section{RESULTS}

The results of experiments analyzing the deiodination of $\left[{ }^{125} \mathrm{I}\right] \mathrm{T}_{4}$ by organotypic and mixed monolayer cultures of type II cells homogenized before incubation are illustrated in Figure 2. All results were obtaind by assessing the chromatographic distribution and $\%$ of products resulting from $\mathrm{T}_{4}$ metabolism, as well as $\%$ $\left[{ }^{125} \mathrm{I}_{\mathrm{T}} \mathrm{T}_{4}\right.$ remaining after the incubation. All results are expressed as the mean $\% \pm 1$ S.D. per $2 \mathrm{mg}$ total homogenate protein, and have already been corrected for both tracer contamination (zerotime controls) and any spontaneous deiodination which occurred

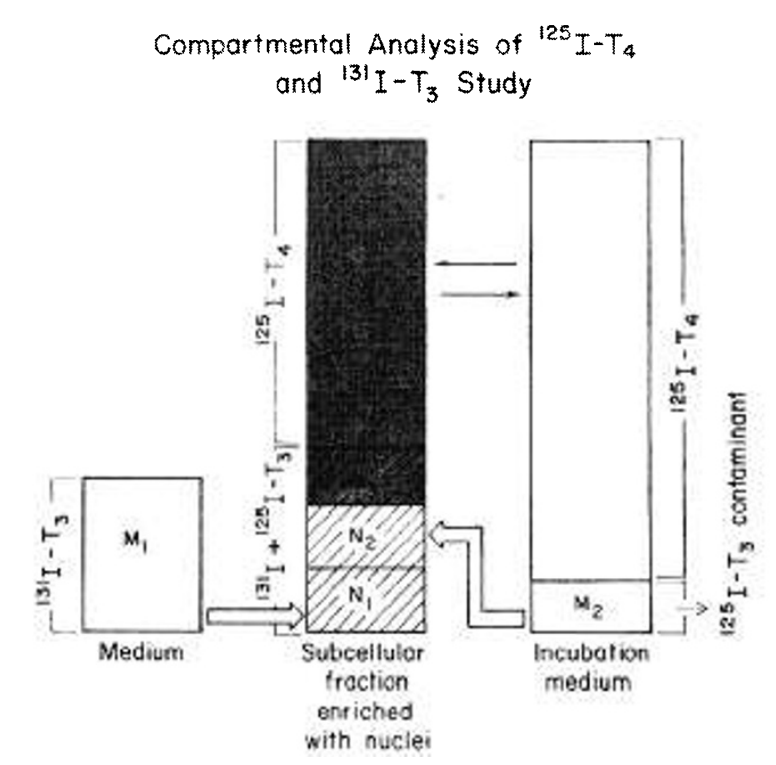

Fig. 1. Schematic drawing representing sources of nuclear $T_{3}$ in organotypic cultures during incubation with $\left[{ }^{125} \mathrm{I}\right] \mathrm{T}_{4}$ and $\left[{ }^{131} \mathrm{I}\right] \mathrm{T}_{3}$. The height of the bars is not a quantitative representation. $N_{1}, N_{2}$, and $N_{3}$ denote $T_{3}$ bound to nuclei derived from the following sources: $N_{1}$ represents [ $\left.{ }^{131} I\right] T_{3}$ derived from the medium $\left[\mathrm{T}_{3}\left(\mathrm{~T}_{3}\right)\right] ; \mathrm{N}_{2}$ is $\left[{ }^{125} \mathrm{I}\right] \mathrm{T}_{3}$ derived from contaminants of the $\left[{ }^{125} I\right] \mathrm{T}_{4}$ utilized; and $\mathrm{N}_{3}$ is the $\left[{ }^{125} \mathrm{I}\right] \mathrm{T}_{3}$ generated de novo during the incubation $\left[N_{2}+N_{3}=T_{3}\left(T_{4}\right)\right] . M_{1}$ is [ $\left.{ }^{131} I\right] T_{3}$ added to the medium. $M_{2}$ is $\left[{ }^{125} I\right] T_{3}$ introduced as a contaminant of the $\left[{ }^{125} I\right] T_{4}$ added to the medium. Thus, $N_{1} / M_{1} \div N_{2}+N_{3} / M_{2}=T_{3}\left(T_{3}\right) \div T_{3}\left(T_{4}\right)=$ " $X$ " (see Table 1).

$$
\begin{aligned}
& { }^{125} I-T_{4} \text { Degradation, }{ }^{125} I-T_{3} \text { and } \\
& { }^{125} I-r T_{3} \text { Generation in Lung Cell Cultures }
\end{aligned}
$$

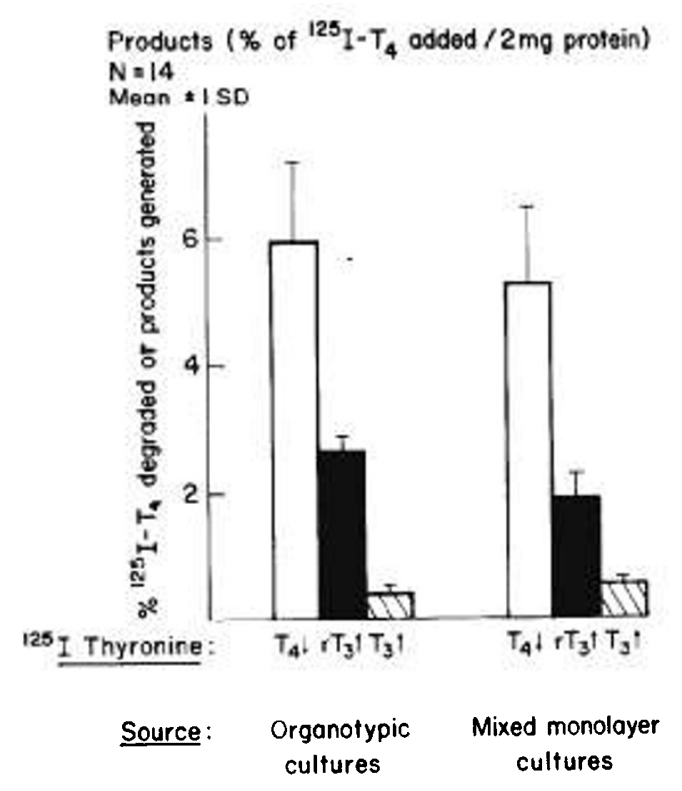

$$
\begin{aligned}
& \text { - Degradation } \\
& + \text { Generation }
\end{aligned}
$$

Fig. 2. Cells were first homogenized and subsequently incubated with $\left[{ }^{125} \mathrm{I}_{\mathrm{T}} \mathrm{T}_{4}\right.$ for $3 \mathrm{~h}$ in the presence of sulfhydryl groups ( $20 \mathrm{mM}$ dithiothreitol, see text). Height of vertical bars indicates the $\%$ of added $\left[{ }^{125} \mathrm{I}\right] \mathrm{T}_{4}$ which was degraded (clear bars) or recovered as $\left[{ }^{125} \mathrm{I}\right] \mathrm{T}_{3}$ (cross hatched) or $\left[{ }^{125} \mathrm{I}\right] \mathrm{r} \mathrm{T}_{3}$ (solid bars). The $\left.\%{ }^{125} \mathrm{I}\right]$ recovered was also calculated but not included in the diagram. The only statistically significant difference between the values for organotypic and mixed monolayer cultures was $\mathrm{rT}_{3}(P<0.05)$. 
during the incubation period (post-incubation controls). For example, the difference between the $\%\left[{ }^{125} \mathrm{I}\right] \mathrm{T}_{3}$ generation in the homogenates of organotypic cultures $(0.83 \pm 0.31)$ and that found in the buffer controls $(0.40 \pm 0.12)$ resulted in a $\%\left[{ }^{125} \mathrm{I}\right] \mathrm{T}_{3}$ generation of $0.43 \pm 0.32$. It should be noted that in all experiments, the buffer controls were significantly different from the cell homogenates (paired Student's $t$ test, $P<0.001$ ). In 14 experiments, the $\%\left[{ }^{25} \mathrm{I}\right] \mathrm{T}_{3}$ generation in organotypic cultures $(0.43 \pm$ 0.32 ) was not significantly different from that in mixed monolayer cell cultures $(0.56 \pm 0.28)$. Both types of preparations showed $\left.{ }^{125} \mathrm{I}\right] \mathrm{T}_{4}$ degradation $(5.89 \pm 2.4$ and $5.41 \pm 3.0$, respectively), and an excess of iodide formation relative to $\left[{ }^{125} \mathrm{I}\right] \mathrm{T}_{3}$ formation (namely, $2.21 \%$ ).

This disproportionate amount of iodide ("excess iodide," see refs. 4 and 5) results whenever $\left[{ }^{125} \mathrm{I}\right] \mathrm{T}_{4}$ labeled in its outer ring gives rise to the degradation products of $\mathrm{rT}_{3}$ (namely, $\mathrm{T}_{2}$ or $\mathrm{T}_{1}$ ). On the other hand, conversion of $\left[{ }^{125} \mathrm{I}\right] \mathrm{T}_{4}$ to $\left[{ }^{125} \mathrm{I}\right] \mathrm{T}_{3}$ yields only one labeled iodide for every labeled molecule of $\mathrm{T}_{3}$ generated. In the homogenization experiments described above, evidence for $\mathrm{rT}_{3}$ formation was obtained by radioautography following twodimensional chromatography of duplicate paper strips, a procedure which separates $\left[{ }^{125} \mathrm{I}\right] \mathrm{r} \mathrm{T}_{3}$ from $\left[{ }^{125} \mathrm{I}\right] \mathrm{T}_{1}$. The $\left[{ }^{125} \mathrm{I}\right] \mathrm{r} \mathrm{T}_{3}$ spot constituted $2.67 \pm 1.1$ of the total activity in the organotypic cultures, and $1.87 \pm 1.0$ of radioactivity in the mixed monolayer cultures $(P<0.05)$.

Figure 3 shows the results of 14 experiments in which $\left[{ }^{125} I\right] \mathrm{T}_{4}$ was incubated with intact cells in organotypic culture. Medium, cells, and subcellular fractions were all analyzed after the incubation. In some experiments, the $\left[{ }^{125} \mathrm{I}\right] \mathrm{T}_{4}$ employed was first purified by passage over an ion exchange column (35). This purified (99\%) $\left[{ }^{125} \mathrm{I}_{\mathrm{T}} \mathrm{T}_{4}\right.$ contained $<0.2 \% \mathrm{~T}_{3}$ and $0.8 \%$ iodide. All results were corrected for impurities and were expressed as the mean \% \pm 1 S.D./mg total homogenate protein. As in the previous experiment, all results (nuclear fraction, homogenized cells and medium) have already been corrected for tracer contamination (zerotime controls) and spontaneous degradation of the $\left[{ }^{125} \mathrm{I}\right] \mathrm{T}_{4}$ (postincubation cell-free medium controls). For example, the uncorrected value for $\left[{ }^{125} \mathrm{I}\right] \mathrm{T}_{3}$ in the nuclear fraction was $9.66 \pm 2.6 \%$. After corrections for tracer contamination and spontaneous deiodination of the $\left[{ }^{125} \mathrm{I}\right] \mathrm{T}_{4}$, this value became $7.75 \pm 2.3 \%$ (see Fig. 3). A net gain of $\left[{ }^{125} \mathrm{I}\right]$ was again apparent, with the distribution favoring the medium rather than the subcellular fractions enriched with nuclei.

The $\%$ of $\left[{ }^{125} \mathrm{I}_{\mathrm{T}} \mathrm{T}_{3}\right.$ (relative to total thyronines) was highest in the subcellular fraction enriched with nuclei $(7.75 \pm 2.3)$ and was significantly different $(P<0.01)$ from the $\%$ of $\left[{ }^{125} \mathrm{I}\right] \mathrm{T}_{3}$ found in the cell homogenate $(4.54 \pm 1.5)$. Both values were higher than the $\left[{ }^{125} \mathrm{I}_{\mathrm{T}} \mathrm{T}_{3}\right.$ found in the medium $(0.18 \pm 0.2)$. Although these results are highly suggestive of de novo $\mathrm{T}_{3}$ generation, they do not conclusively confirm such an enzymatic process because this experimental protocol can not distinguish de novo generation from simple influx of $T_{3}$ from the medium. The high $\%$ of $T_{3}$ in the nuclei might simply represent the high affinity of the nuclear compartment for $T_{3}$.

Confirmation of $\left[{ }^{125} \mathrm{I}\right] \mathrm{T}_{3}$ generation by the cells was obtained from the experiments utilizing two isotopes (Table 1). After the incubation of cells in labeled medium and subsequent chromatography of aliquots of both subcellular fractions enriched with nuclei and media, assessment of total $\left[{ }^{125} I\right] T_{3}$ and $\left.{ }^{131} I\right] T_{3}$ was made by multiplying the $\% \mathrm{~T}_{3}$ (obtained by chromatography) by the total counts. The compartments indicated in Figure 1 illustrate schematically how the $\mathrm{N}: \mathrm{M}$ ratios were derived. As already stated, a ratio ("X") of $T_{3}\left(T_{3}\right) / T_{3}\left(T_{4}\right)$ of less than 1 is evidence for de novo generation of $T_{3}$ from $T_{4}$ in the cells. Table 1 presents the results of five experiments. A mean of 0.68 was obtained for this ratio. Utilizing these ratios, the \% of $\mathrm{T}_{3}$ bound to nuclei which was generated de novo as contrasted with that resulting from simple influx can be calculated. Of all the $T_{3}$ bound to the nucleus, $32 \%$ arises from de novo generation in day 19 fetal lung cells (Table 1). This does not appear to hold true for type II cells derived from earlier gestational stages. Preliminary data using
Degradation of ${ }^{125} \mathrm{I}-\mathrm{T}_{4}$ and Profile of Deiodination Products (expressed as $\%$ added $\mathrm{T}_{4} / \mathrm{mg}$ protein)
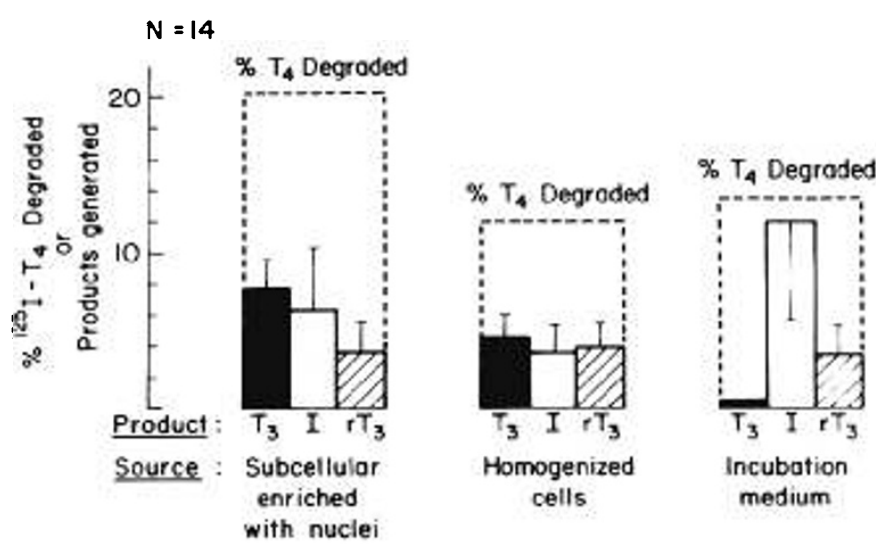

Fig. 3. The distribution of radioactive compounds in organotypic cultures expressed as $\%$ of $\left[{ }^{125} \mathrm{I}\right] \mathrm{T}_{4}$ added to $5 \times 10^{7}$ cells $(1.0-1.1 \mathrm{mg}$ protein) analyzed after $36 \mathrm{~h}$ incubation. The $\% \mathrm{~T}_{4}$ degraded and the content of thyronines and iodide are compared in the nuclear fraction, homogenized cells, and medium. Results are expressed as $\%$ of added $\left[{ }^{125} \mathrm{I}\right] \mathrm{T}_{4} / \mathrm{mg}$ total homogenate protein and corrected for both contaminants and spontaneous degradation. Results shown represent the mean \pm S.D. Concentrations of $\left[{ }^{125} \mathrm{I}\right] \mathrm{T}_{3}$ and $\left[{ }^{125} \mathrm{I}\right]$ were statistically different $(P<0.01)$ when medium, cells, and nuclear fractions were compared by Duncan's multiple range test (13). Differences of $\left[{ }^{125} \mathrm{I}\right] \mathrm{r} \mathrm{T}_{3}$ were not significant.

Table 1. Sources of nuclear triiodothyronine in organotypic cultures incubated with $\left[{ }^{125} \mathrm{I}\right] T_{4}$ and $\left[{ }^{131} \mathrm{I}\right] \mathrm{T}_{3}{ }^{1}$

\begin{tabular}{|c|c|c|c|c|}
\hline \multirow[b]{2}{*}{ Experiment } & \multicolumn{2}{|c|}{$\mathrm{N}: \mathrm{M}$ ratios } & \multirow{2}{*}{$\begin{array}{l}\text { Ratio } \\
\text { "X"4 }\end{array}$} & \multirow[b]{2}{*}{$1-" X "}$. \\
\hline & $\mathrm{T}_{3}\left(\mathrm{~T}_{3}\right)^{2}$ & $T_{3}\left(T_{4}\right)^{3}$ & & \\
\hline 1 & 0.028 & 0.031 & 0.90 & 0.10 \\
\hline 2 & 0.018 & 0.028 & 0.64 & 0.36 \\
\hline 3 & 0.019 & 0.028 & 0.67 & 0.33 \\
\hline 4 & 0.019 & 0.032 & 0.59 & 0.41 \\
\hline 5 & 0.014 & 0.023 & 0.61 & 0.39 \\
\hline Mean & $0.020 \pm 0.005^{6}$ & $0.028 \pm 0.004^{6}$ & $0.68(68 \%)$ & $0.32(32 \%)$ \\
\hline
\end{tabular}

${ }^{1}$ The organotypic cultures were incubated for $36 \mathrm{~h}$. The medium $T_{4}$ concentration in all experiments was $4 \mathrm{ng} / \mathrm{ml}$ and medium $\mathrm{T}_{3}$ concentrations were $1.5 \mathrm{ng} / \mathrm{ml}$.

${ }^{2} \mathrm{~T}_{3}\left(\mathrm{~T}_{3}\right)$ denotes nuclear $\left[{ }^{131} \mathrm{I}\right] \mathrm{T}_{3}$ transported from the $\left[{ }^{131} \mathrm{I}\right] \mathrm{T}_{3}$ pool in the medium (also see Fig. 1).

${ }^{3} \mathrm{~T}_{3}\left(\mathrm{~T}_{4}\right)$ denotes nuclear $\left[{ }^{125} \mathrm{I}\right] \mathrm{T}_{3}$ derived from contaminants of the $\left[{ }^{[25} \mathrm{I}\right]$ $\mathrm{T}_{4}$ added, in addition to $\left[{ }^{12.5} \mathrm{I}\right] \mathrm{T}_{3}$ generated de novo.

${ }^{4}$ " $X$ " is the ratio $T_{3}\left(T_{3}\right)$ divided by $T_{3}\left(T_{4}\right)$.

${ }^{5} 1$ - " $X$ " represents the \% of bound nuclear $T_{3}$ which has been generated de novo.

${ }^{6}$ Mean \pm S.D.

cells derived from 16-day fetuses show that although the nuclear fraction was enriched with $T_{3}$, the value for " $X$ " was greater than 1.

Further evidence for de novo $\left[{ }^{125} \mathrm{I}\right] \mathrm{T}_{3}$ generation was obtained from the experiments in which highly purified $\left[{ }^{125} \mathrm{I}\right] \mathrm{T}_{4}$ was employed. During this procedure, strict "net accounting" was kept by adding all media and cellular counts together. In these experiments, the net gain of $\left.{ }^{125} \mathrm{I}\right] \mathrm{T}_{3}$ was as high as $1.3 \%$ of the $\left[{ }^{125} \mathrm{I}\right] \mathrm{T}_{4}$ counts added to the incubation system (for details of calculation see "Appendix").

\section{DISCUSSION}

Although numerous studies have suggested that both $T_{4}$ and $T_{3}$ produce significant effects on fetal lung differentiation, no studies to date have examined the metabolism of $T_{4}$ by the lung as 
compared to other developing organs. Since circulating $T_{4}$ levels are low in the perinatal rat, and serum $T_{3}$ levels virtually unmeasurable for the first few days of neonatal life $(16,19)$, the elucidation of regulation of thyroid hormone metabolism at the local target site is critical. The present studies clearly demonstrate that type II cells homogenized before short term incubations, as well as intact organotypic lung cultures incubated for long periods, have the capacity to monodeiodinate $T_{4}$. These cells must, therefore, have the enzymatic mechanisms required, including the necessary cofactors and sulhydryl group generating system, assumed to be essential for this reaction $(9,18)$.

Of equal interest is the identification of the products generated in the course of $T_{4}$ metabolism. It is now well recognized that $T_{4}$ can be converted peripherally to two major products of monodeiodination by deiodination of its phenolic or outer ring to form $\mathrm{T}_{3}$, and deiodination of its tyrosyl or inner ring to form $\mathrm{rT}_{3}(4-8)$. Often, the products thus formed are metabolized further to $3,3^{\prime} \mathrm{T}_{2}$ and $T_{1}$. In this manner each tissue is offered alternate local pathways for either increasing thyroid hormone action by producing $T_{3}$ or blunting its action by producing $\mathrm{rT}_{3}(6)$. In the cerebral cortex and pituitary, $\mathrm{T}_{3}$ production is increased in hypothyroid states $(8,23)$. In the liver, on the other hand, $T_{3}$ production decreases during starvation $(4-6,19,24)$.

In these experiments fetal lung cells were shown to be capable of production of both $\mathrm{T}_{3}$ and $\mathrm{rT}_{3}$ from $\mathrm{T}_{4}$. Indeed, the deiodination of $T_{4}$ by the homogenized fetal lung cells appeared to favor tyrosyl ring deiodination. The production of excess iodide $\left(\%\left[{ }^{125} \mathrm{I}\right]\right.$ formed - \% [ ${ }^{125} \mathrm{I}_{\mathrm{T}} \mathrm{T}_{3}$ generated) corroborates this finding because, once formed, $\mathrm{rT}_{3}$ is much more rapidly metabolized to $3,3^{\prime \prime} T_{2}$ and $T_{1}$ than is $T_{3}$. Hence, the production of excess iodide has been assumed to be indirect evidence for 5-monodeiodinase activity with the consequent formation of $\mathrm{rT}_{3}$.

These observations are in keeping with the fact that fetal life is characterized by low $\mathrm{T}_{3}$ levels $(10,16,19,24,38)$. The most important difference in thyroid hormone economy between the mature organism and the fetus is the presence of $\mathrm{rT}_{3}$ in fetal serum, amniotic fluid $(10,16)$, and organs such as cerebral cortex (23) and liver $(16,19,38)$. In part, the high levels of $\mathrm{rT}_{3}$ in body fluid compartments result from decreased metabolic clearance (10); however, the major factor is the increased peripheral conversion of $\mathrm{T}_{4}$ to $\mathrm{rT}_{3}(10,16,38)$. Because the fetus is well provided with nutrients and oxygen and does not depend on metabolic processes for thermal regulation, the production of $\mathrm{rT}_{3}$ instead of $\mathrm{T}_{3}$ may have a protective effect, permitting the sparing of fuels required for growth and cell differentiation. On the other hand, the complexity of enzyme systems in various developing organs defies a unitarian explanation. For example, fetal and early neonatal rat liver cells and hepatocarcinoma cells have the capacity to produce large amounts of $\mathrm{rT}_{3}(15,28,36)$; the shift to substantial $\mathrm{T}_{3}$ generation occurs only after $2-3$ wk of neonatal life $(7,19)$. In the developing pituitary, the maturation of enzyme capacity is characteristically opposite: $T_{3}$ generation being high early in neonatal life and then decreasing to adult levels (7). Cerebral cortex and the cerebellar hemispheres display still different enzyme patterns (23). In addition, the $\mathrm{Km}$ of the deiodinating enzymes differs in these organ systems suggesting isoenzyme groups which may alter and become differentiated as development proceeds (29). In tumour tissues there is generally de-differentiation of these deiodinating enzyme systems $(15,36)$.

In the fetal rat lung, the $\%$ of $T_{3}$ formed in homogenates $(0.43)$ was small but statistically significant when compared with appro-

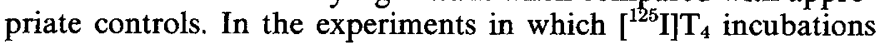
were conducted in intact cells, both hormone metabolism and distribution could be assessed. Although $\left.{ }^{125} \mathrm{I}\right] \mathrm{rT}_{3}$ was equally distributed between cells and medium, the $\left[{ }^{125} \mathrm{I}\right] \mathrm{T}_{3}$ present $(7.75 \%)$ showed highest affinity for the nuclear fraction. Iodide, on the other hand, was found predominantly in the medium. Although de novo generation of $\mathrm{T}_{3}$ could not be separated from simple influx of $T_{3}$ from the medium in these experiments, coupled with the results of the dual label studies, an assessment of de novo $\mathrm{T}_{3}$ generation can be made. In these experiments, $32 \%$ of the nuclear
$T_{3}$ was calculated to be newly generated. Although this value is considerably less than that reported for the rat pituitary (8), it does represent a significant de novo generation of $\mathrm{T}_{3}$ in fetal cells. Similar studies are now planned utilizing cells derived from neonatal animals. These findings corroborate the results of immunohistochemical studies which have demonstrated $T_{3}$ in type II cells in culture (37), and studies that have demonstrated the existence of specific nuclear $T_{3}$ receptors in cultured fetal rabbit (3) and human (17) lung cells.

In summary, the results of these studies indicate that the fetal rat lung is capable of $T_{3}$ generation. Although the physiologic importance of this $T_{3}$ neogenesis remains unclear, it is quite possible that $\mathrm{T}_{3}$ exerts the biologic effects of thyroid hormone and, therefore, is responsible for the morphologic changes in fetal and adult type II cells which have been described by a number of investigators (for review, see 20-22). It is also possible that $T_{4}$, rather than acting as a prohormone, has effects of its own, and that in the course of its activity it is metabolized peripherally to other thyronines such as $\mathrm{T}_{3}$ and $\mathrm{rT}_{3}$. These compounds might then simply represent by-products of thyroid hormone action. The more likely explanation, however, is that the active metabolism of $T_{4}$ to $T_{3}$ observed in cultures of fetal lung cells is important to normal developmental events in the lung. Experiments utilizing inhibitors of $T_{4}$ deiodination are in progress to elucidate the particular developmental events affected by $T_{3}$.

\section{APPENDIX}

\section{NET ACCOUNTING OF RADIOACTIVE COUNTS}

1. $\left[{ }^{125}{ }^{12}\right] \mathrm{T}_{4}$ counts $/ \mathrm{min}$ added to $10 \mathrm{ml}$ medium. $=30,000,000$.

2. Recovery of $\left[{ }^{125} \mathrm{I}\right]$ counts in medium post-incubation.

The number of these counts attributable to $\left[{ }^{125} \mathrm{I}\right] \mathrm{T}_{3}$ in medium as assessed by chromatography of an aliquot $(1.8 \%$ of $28,500,000)$.

$=28,500,000$. 3. Total $\left[{ }^{125} \mathrm{I}\right]$ counts in pellet before fractionation. $=500,060$.

4. $\left[{ }^{125} \mathrm{I}\right]$ counts in the nuclear fraction (after sucrose gradient centrifugation of pellet).

5. Counts in the nuclear fraction attributable to $\left.{ }^{[25} \mathrm{I}\right] \mathrm{T}_{3}$ (after chromatography).

6. Total $\left[{ }^{125} \mathrm{I}\right] \mathrm{T}_{3}$ counts in medium and nuclear fraction $=(2)+(5)$.

7. Estimated portion of $\left[{ }^{125} \mathrm{I}_{3} \mathrm{~T}_{3}\right.$ counts in medium at the end of the incubation derived from both contaminants and spontaneous degradation of the $\left[{ }^{125} \mathrm{I}\right] \mathrm{T}_{4}$ utilized $(0.5 \% \times 28,500,000)$.

50,006 . 8. Therefore, newly generated $\left[{ }^{125} \mathrm{IJT}_{3}=(6)-(7) .=373,600\right.$. This represents $1.32 \%$ of total counts.

\section{REFERENCES AND NOTES}

1. Ballard, P. L., Brehier, A., Benson, B. J., Kriz, B. M., and Jorgenson, E. C.: Transplacental effects of a thyroxine analog on phospholipid synthesis in fetal rabbit lung. Pediatr. Res., 12: 558 (1978).

2. Ballard, P. L., Benson, B. J., Brehier, A., and Carter, J. P.: Transplacental stimulation of lung development in the fetal rabbit by 3,5-dimethyl $3^{\prime}$-isopropyl-L-thyronine. J. Clin. Invest., 65: 1407 (1980).

3. Ballard, P. L., Lindenberg, J. A., and Brehier, A.: Triiodothyronine nuclear binding in rabbit lung and cultured lung cells. Pediatr. Res., 12: 410 (1978).

4. Balsam, A., Sexton, F., and Ingbar, S. H.: Observations on the factors that control the generation of triiodothyronine from thyroxine in rat liver and the nature of the defect induced by fasting. J. Clin. Invest., 63: 1145 (1979).

5. Balsam, A., Sexton, F., and Ingbar, S. H.: On the mechanism of impaired in vitro generation of $3,5,3^{\prime}$-triiodothyronine from thyroxine in livers of hypothyroid rats. Endocrinology, 105: 1115 (1979)

6. Braverman, L. E., Sterling, K., and Ingbar, S. H.: Conversion of thyroxine $\left(\mathrm{T}_{4}\right)$ to triiodothyronine $\left(\mathrm{T}_{3}\right)$ in athyreotic human subjects. J. Clin. Invest., 49: 855 (1970).

7. Cheron, R. G., Kaplan, M. M., and Larsen, P. R.: Divergent changes of thyroxine5 -monodeiodination in rat pituitary and liver during maturation. Endocrinology, 106: 1405 (1980)

8. Cheron, R. G., Kaplan, M. M., and Larsen, P. R.: Physiological and pharmacological influences on thyroxine to $3,5,3^{\prime}$-triiodothyronine conversion and nuclear $3,5,3^{\prime}$-triiodothyronine binding in rat anterior pituitary. J. Clin. Invest., 64: 1402 (1979). 
9. Chopra, I. J.: Sulfhydryl groups and the monodeiodination of thyroxine to triiodothyronine. Science, 199: 904 (1978)

10. Chopra, I. J., Sack, J., and Fisher, D. A.: 3,3', $5^{\prime}$-triiodothyronine (reverse $T_{3}$ ) and 3,3'5-triiodothyronine $\left(\mathrm{T}_{3}\right)$ in fetal and adult sheep: Studies of metabolic clearance rates, production rates, serum binding and thyroidal content relative to thyroxine. Endocrinology, 97: 1080 (1975)

11. Douglas, W. H. J., DelVecchio, P., Teel, R. W., Jones, R. M., and Farrell, P. M.: Culture of type II lung cells: In: A. Bouhuys, Ed.: Lung Cells in Diseases. pp. 53-68 (Elsevier, Amsterdam 1976).

12. Douglas, W. H. J. and Teel, R. W.: An organotypic in vitro model system for studying pulmonary surfactant production by type II alveolar pneumonocytes. Am. Rev. Resp. Dis., 113: 17 (1976).

13. Dunnett, C. W: Multiple comparisons. In: J. W. McArthur and T. Colton, Eds. Statistics in Endocrinology. Vol. 1, p. 86 (MIT Press, Cambridge, MA, 1970).

14. Farrell, P. M., Lundgren, D. W., and Douglas, W. H. J.: Enzymatic synthesis of phosphatidylcholine (PC) in homogeneous cultures of apparent type II pneumocytes. Pediatr. Res., 9: 276 (1975).

15. Farron, F., Hsu, H. H. T., and Knox, W. E.: Fetal-type isoenzymes in hepatic and nonhepatic rat tumors. Cancer Res., 32: 302 (1972).

16. Fisher, D. A. and Sack, J.: Thyroid hormone metabolism in amniotic fluid of man and sheep. In: D. A. Fisher and G. N. Burrow, Eds.: Perinatal Thyroid Physiology and Disease. pp. 49-58 (Raven Press, New York, 1975)

17. Gonzales, L. W. and Ballard, P. L.: Identification and characterization of nuclear 3,5, ' 'triiodothyronine-binding sites in fetal human lung. J. Clin. Endocrinol. Metab., 53: 21 (1981)

18. Harris, A. R. C., Fang, S. L., Hinerfeld, L., Braverman, L. E., and Vagenakis, A. G.: The role of sulfhydryl groups on the impaired hepatic, 3', 3,5-triiodothyronine generation from thyroxine in the hypothyroid, starved, fetal, and neonatal rodent. J. Clin. Invest., 63: 516 (1979).

19. Harris, A. R C. Fang, S. L., Prosky, J., Braverman, L. E., and Vagenakis, A. G.: Decreased outer ring monodeiodination of thyroxine and reverse triiodothyronine in the fetal and neonatal rat. Endocrinology, 103: 2216 (1978).

20. Hitchcock, K. R.: Hormones and the lung. I. Thyroid hormones and giucocorticoids in lung development. Anat. Rec., 194: 15 (1979).

21. Hitchcock, K. R.: Lung development and the pulmonary surfactant system: Hormonal influences. Anat. Rec., 198: 13 (1980).

22. Hitchcock, K. R., Harney, J., and Reichlin, S.: Hormones and the lung. III. Thyroid hormone uptake kinetics of perinatal rat lung. Endocrinology, 107: 294 (1980)

23. Kaplan, M. M. and Yaskoski, K. A.: Maturational patterns of iodothyronine phenolic and tyrosol ring deiodinase activities in rat cerebrum, cerebellum and hypothalamus. J. Clin. Invest., 67: 1208 (1981).

24. Larsen, P. R., Silva, J. E., and Kaplan, M. M.: Relationships between circulating and intracellular thyroid hormones: physiological and clinical implications. Endocrine Reviews, 2: 87 (1981)

25. Lowry, O. H., Rosebrough, N. J., Farr, A. L., and Randall, R. J.: Protein measurement with the Folin phenol reagent, J. Biol. Chem., 193: 265 (1951).

26. Oppenheimer, J. H., Schwartz, H. L., and Surks, M. I.: Tissue differences in the concentration of triiodothyronine nuclear binding sites in the rat: Liver, kidney, pituitary, heart, brain, spleen and testis. Endocrinology, 95: 897 (1974).

27. Redding, R. A., Douglas, W. H. J., and Stein, M.: Thyroid hormone influence upon lung surfactant metabolism. Science, 175: 994 (1972).

28. Sato, $\mathrm{K}$. and Robbins, J.: Thyroid hormone metabolism in cultured monkey hepatocarcinoma cells. Monodeiodination activity in relation to cell growth. J.

Copyright (C) 1983 International Pediatric Research Foundation, Inc. $0031-3998 / 83 / 1706-0596 \$ 02.00 / 0$
Biol. Chem., 255(15): 7347 (1980).

29. Segall-Blank, M., Balsam, A., and Ingbar, S. H.: Evidence of an altered $S^{\prime}$ monodeiodinase for thyroxine in the liver of the fetal rabbit. Pediatr. Res., 15: 1123 (1981).

30. Silva, J. E Kaplan, M., Cheron, R. G., Dick, T. E., and Larsen, P. R.: Thyroxine to $3,5,3^{\prime}$-triiodothyronine conversion by rat anterior pituitary and liver. Metab. Clin. Exp., 27: 1601 (1978).

31. Silva, J. E. and Larsen, P. R.: Pituitary nuclear 3,5,3'-triodothyronine and thyrotropin secretion: An explanation for the effect of thyroxine. Science, 198: 617 (1979).

32. Silva, J. E. and Larsen, P. R.: Contributions of plasma triiodothyronine and local thyroxine to triiodothyronine monodeiodination to nuclear triiodothyronine receptor saturation in pituitary, liver and kidney of hypothyroid rats. Further evidence relating saturation of pituitary nuclear triiodothyronine receptors and the acute inhibition of thyroid-stimulating hormone release. J. Clin. Invest., 61: 1247 (1978).

33. Smith, B. T. and Torday, J. S.: Factors affecting lecithin synthesis by fetal lung cells in culture. Pediatr. Res., 8: 848 (1974).

34. Sommers, S. K., Sanders, R. L., Hitchcock, K. R., and Douglas, W. H. J.: Effect of triiodothyronine $\left(\mathrm{T}_{3}\right)$ on organotypic cultures of alveolar type II cells. Fed. Proc., 39(I-3): 1065 (I980).

35. Sorimachi, K. and Ui, N.: Ion-exchange chromatography of iodothyronines. Anal. Biochem., 67: 157 (1975).

36. Sorimachi, K., Niwa, A., and Yasumura, Y.: Activation and inactivation of thyroxine by cultured rat hepatoma cells. Biochem. Biophys. Acta, 633: 134 (1980).

37. Wilson, M. Hitchcock, K. R., Douglas, W. H. J., and DeLellis, R.: Immunohistochemical localization of thyroid hormone binding in type II pulmonary epithelial cells clonally-derived from adult rat lung. Anat. Rec., 195: 611 (1979).

38. Wu, S. Y., Klein, A. H., Chopra, I. J., and Fisher, D. A.: Alterations in tissue thyroxine-5' monodeiodinating activity in perinatal period. Endocrinology, 103: 235 (1978).

39. The materials employed were purchased from the following commercial sources: Phenolic ring [ $\left.{ }^{125} \mathrm{I}\right]$-labeled L-thyroxine $\left(\left[{ }^{125} \mathrm{I}_{\mathrm{T}} \mathrm{T}_{4}, 1006-1200 \mu \mathrm{Ci} / \mu \mathrm{g}\right)\right.$ from Abbott Laboratories, North Chicago, Illinois; crystalline $T_{4}$ and dithiothreitol, from Sigma Chemical Co., St. Louis, MO; and Sprague-Dawley rats from Taconic Farms, Germantown, New York.

40. Presented in part at the Annual Meeting of the American Pediatric Society and the Society for Pediatric Research, San Francisco, April 28th-May 1st, 1981.

41. Monolayer cultures were kindly supplied by Dr. Barry Smith, Department of Pediatrics, Harvard Medical School. We thank him for this gift

42. The authors would like to thank Dr. Sidney H. Ingbar, Beth Israel Hospital, and Dr. P. R. Larsen, Peter Bent Brigham Hospital, for their helpful suggestions and advice.

43. Requests for reprints should be addressed to: Dr. Karen Hitchcock, Professor and Chairman, Department of Anatomy and Cellular Biology, Tufts University School of Medicine, 136 Harrison Avenue, Boston, MA, 02111.

44. Dr. Margot Blank was supported as a "Parker B. Francis Foundation Fellow in Pulmonary Research".

45. This study was supported in part by Grant HL 26690 from the National Heart, Lung and Blood Institute, N.I.H.

46. Received for publication March 23, 1982

47. Accepted for publication October 1,1982

Printed in U.S.A. 